A Lord Chancellor in office or retired could not be expected to do much of the actual scientific work himself, though the corpus of his experimental observations is substantial. But he was eager "to set the machine in motion". On his last journey, from London to Highgate, he thought of an untried experiment on refrigeration. Stepping from his coach, he procured at a cottage the body of a hen and stuffed it with snow. As often happens to scientific researchers, especially into tropical diseases, he became the victim of the incidents of his own experiment. Seized by the cold, he was put to bed in the neighbouring house of Lord Arundel and died in a few days, on Easter Sunday 1626, choking and struggling with bronchitis. He was able to say in his last letter, dictated to his host, that "As for the experiment itself, it succeeded excellently well". It was all that mattered. As a dying gesture, he carried out a successful experiment. Some centuries were to elapse before this simple experiment became the corner-stone of a great industry.

Bacon's life from the time he left Cambridge was a protest against syllogisms, the raw material of the scholastic philosophers, the "babbling sophists", whose aim in life was "to overcome an opponent in argument"--or burn him, as happened to Bruno, or immure him, as happened to Galileo. Bacon held that man's true mission was "to command nature in action". Like a great general, he planned the campaign in the "Advancement of Learning" and the "Novum Organum". First the facts of Nature "free and at large" must be collected. The synthesis, like Tipperary, was a long, long way. Bacon knew he would never write that final chapter; he looked to humanity to continue and even to complete the work, keeping their eyes always on the object and clearing their minds of cant. "The whole of Nature being explored and understood", his biographer, Charles Williams, writes, "the whole of its operations lying open, truth (so far as the nature of things was concerned) being flagrant and ostensible, the final declaration of that philosophy would be achieved".

Bacon aspired after truth, "Immortal, incorruptible, sovereign truth". But if we wish to know why he would set men "finding out the true nature of all things", and create a Solomon's House for this great work, why not look for the reasons in "New Atlantis"? There they are, bellclear, convincing - "whereby God might have the more glory in the workmanship of them, and men the more fruit in the use of them". T. Ll. H.

\title{
Obituary
}

Major C. K. Cochran-Patrick, D.S.o., M.c. THE daily Press has recorded the aeroplane disaster at Johannesburg on September 26 which resulted in the deaths of Major C. K. Cochran-Patrick, and his companion, Sir Michael Oppenheimer, a member of a family well known on the Rand. That a pilot of the highest skill, with vast experience of flying in four continents, should crash immediately after taking off from an aerodrome, must be attributed to some peculiar laxity or abnormal circumstance. The loss of a life so valuable is particularly regrettable, since after attaining the highest reputation in the military sphere, it was hoped that CochranPatrick would attain to similar eminence in promoting the more scientific development of civil aviation, especially in the realm of air survey wherein his later interests chiefly lay.

After undertaking some pioneer work in Venezuela, Cochran-Patrick went to Burma to photograph from the air the delta of the Irawadi. Here there was much illegal cutting of the valuable teak forest, but in the absence of a proper map of the area it was impossible to assess the extent of the damage or control the depredation. The area was very difficult of access and survey by ordinary methods was next to impossible. The air photographs taken by Cochran-Patrick, in conjunction with trigonometrical surveys of the creeks executed by Lieut.-Col. Lewis of the Survey of India, resulted in the successful mapping of the whole area; even the photographs themselves were of the greatest value to the Forestry Department, since it was then proved conclusively that the several types of vegetation could be differen tiated on the prints. Apart from survey itself, a new use was thus found for air photographs. We consider this to have been Cochran-Patrick's most fruitful civil work; moreover, it pointed out conditions under which air survey could be employed with greatest success.

From the Air Survey Co., Cochran-Patrick transferred his services to the Aircraft Operating Co. and carried out surveys for the latter in Rhodesia, Iraq and elsewhere. Perhaps his most interesting job in Rhodesia was the photographic survey of the upper tributaries of the Zambezi River in order to study its hydrology; much useful information was thus gained without the delays and dangers consequent on painful penetration. Further work was accomplished in Northern Rhodesia in areas where mineral development was in progress and land settlement was proposed.

In the intervals between these surveys in the field, Cochran-Patrick was engaged in seeking the improvement and quickening of technical pro. cesses. If he did not himself discover a new method of air survey, at any rate he applied himself actively to the development of methods already in existence ; improved means of handling large mosaics of photographs and constructing the map therefrom demanded patient research and detailed study of processes. The loss of Cochran. 
Patrick, brave and modest, has occurred in the prime of life, at the early age of thirty-seven years; his departure will be deplored by a large circle of friends.

\section{Prof. R. Ramsay Wright}

WE regret to record the death on September 5 of Robert Ramsay Wright, emeritus professor of biology in the University of Toronto. Prof. Wright was a child of the manse and was born at Alloa, Scotland, in the year 1853. His early education was obtained at the Edinburgh High School, whence he proceeded to the University of Edinburgh, receiving in due time the degrees of M.A. (1871) and B.Sc. (1873). He acted for a time as assistant to the professor of natural history at Edinburgh, but in 1874 he was called to the University of Toronto to succeed Prof. H. A. Nicholson in the chair of natural history, his title being later changed to professor of biology.

Prof. Wright proved to be an attractive and inspiring teacher, and early introduced practical instruction on the lines developed by Huxley and Martin. The growth of his department soon called for more suitable accommodation than was at first available, and he planned and carried to completion the erection of a Biological Building, which included an unusually complete teaching Museum of Zoology and from which Departments of Botany and Physiology later budded off. His administrative abilities led to his appointment in 1901 to the office of vice-president of the University, an office which he retained until his retirement from active service in 1912, when he returned to Great Britain and took up his residence in Oxford.

Administrative duties seriously interfered with
Prof. Wright's marked ability for research, shown by his early contributions to Canadian helminthology and later by his studies of the so-called auditory apparatus of the siluroid fishes. With the collaboration of some former pupils, he published a polygraph of the anatomy of the catfish (Amiurus catus), he himself supplying the sections on the nervous system and sense organs. But his interests were very broad; he was a musician of no mean order and an exceptional linguist ; indeed, his latest completed work was a translation of a Persian medical MS. by al-Biruni.

Recognition of Prof. Wright's attainments was frequent, both from Canada and from his motherland. He received the honorary degree of LL.D. from Edinburgh and Toronto and an honorary M.A. from Oxford. $\mathrm{He}$ was president of the Canadian Institute in 1893-95 and contributed on occasion to its Proceedings; he was a charter fellow of the Royal Society of Canada and its president in 1910-11, and as an original member of the Biological Board of Canada he played an important part in the establishment and development of that organisation. Canadian biology owes much to his enthusiasm, his stimulating teaching and his scholarship. J. P. McM.

WE regret to announce the following deaths:

Sir Arthur Mayo-Robson, K.B.E., C.B., C.V.O., emeritus professor of surgery in the University of Leeds, and honorary president of the Surgical Section of the Thirteenth International Medical Congress in Paris in 1900, on October 12, aged eighty years.

The Hon. Lady Parsons, widow of the late Sir Charles Parsons, and one of the founders of the Women's Engineering Society, on October 16.

\section{News and Views}

\section{Centenary of Alfred Nobel, I833-I896}

ON October 21 occurs the centenary of the birth of Alfred Bernhard Nobel, the eminent Swedish engineer, inventor and industrialist, who left the greater part of his fortune to found the Nobel prizes. He was the third of the four sons of Emmanuel Nobel (1801-72) who for many years had works in St. Petersburg, where contracts were carried out for the Russian government, and like his brothers, Alfred was trained in his father's shops. At an early age, his attention was attracted to the subject of explosives, which had entered upon a new phase of development through the invention in 1846 of guncotton by Schönbein and of nitro-glycerine by Sobrero in the following year. Experimenting with these new substances, Nobel discovered that nitro-glycerine can be detonated by a small charge of fulminate of mercury, and next found that by mixing nitroglycerine with the porous earth kieselguhr, he could produce an explosive in a form which could be handled easily and safely. To this substance, which he patented in Sweden on September 19, 1867, he gave the name 'dynamite'. In later years he produced blasting gelatine, ballistite and other explosives, for the manufacture of which works were erected in many parts of the world. Some of Nobel's wealth was derived from his association with his elder brothers, Hjalmar Nobel (1829-1896) and Ludwig Nobel (1831-1888) in their remarkable exploitation of the Baku oil fields and their methods of transporting oil by pipe lines, tank cars and tank steamers. Nobel's death took place at San Remo on December 10 , 1896, and by a will which was signed in 1895 , about $\mathfrak{£ 1 , 4 0 0 , 0 0 0}$ became available for the foundation of the famous prizes awarded annually for notable work done in physics, chemistry, medicine or physiology, and literature and in the cause of peace. The first awards were made on December 10, 1901, five years after Nobel's death. 